\title{
Masalah Ketidakmerataan Pendidikan Formal Di Indonesia
}

\section{Wanda Aprilla}

Berdasarkan fakta dilapangan mengenai pendidikan di Indonesia saat ini yaitu terjadinya ketidakmerataan pendidikan formal di daerah pedalaman atau perbatasan, masih banyak anak-anak Indonesia yang tidak bisa memperoleh pendidikan karena beberapa faktor yang mendorong hal tersebut. Hal ini terjadi akibat adanya kesulitan memperoleh pendidikan, padahal permasalahan ini merujuk pada undang -undang 45 pasal 31 yang menyatakan bawa setiap warga negara memiliki hak untuk memperoleh pendidikan dan warga negara wajib mengikuti pendidikan dasar dan pemerintah wajib dibiayai pendidikan tersebut. Akan tetapi, yang terjadi pada saat ini tidak demikian.

Pada daerah perkotaan, sekolah yang berstatus pendidikan formal sangatlah mudah ditemukan. Sehingga anak-anak kota lebih mudah mendapatkan pendidikan dari pendidikan dasar sampai menengah atas. Berbanding terbalik dengan daerah pedalaman, atau perbatasan. Anak-anak yang tinggal didaerah pedalaman atau perbatasan kesulitan mendapat pendidikan karena didaerah mereka ada yang tidak memiliki sekolah. Dampak yang terlihat dari hal ini adalah adanya ketidakmerataan penyelenggaraan pendidikan antara daerah perkotaan dengan daerah pedalaman atau perdesaan.

Setiap masalah terjadi karena adanya sebab dan akibat, permasalahan ini dapat dilihat dari sebab mengapa daerah perkotaan lebih mudah memperoleh pendidikan dibanding daerah pedalaman atau perbatasan, sebagai gambaran fenomena ini yang tertuang dalam film yang dibuat oleh anak Indonesia yang berjudul " Aku dan Hari Esok ". Film ini menggambarkan bagaimana pendidikan Indonesia tidak dapat menjangkau seluruh daerah di Indonesia terlebih lagi didaerah perbatasan. Berdasarkan fakta yang ada, faktor yang mendorong terjadinya ketidakmerataan pendidikan di Indonesia didaerah pedalaman atau perbatasan terjadi karena pemerintah kurang memperhatikan pendidikan didaerah pedalaman atau perbatasan tersebut, selain itu akses untuk menuju daerah tersebut terbilang sulit untuk melakukan pembangunan sekolah dan pemenuhan fasilitas sarana dan prasarana didaerah tersebut. Faktor lain yang mendorong hal ini ialah orang tua daerah tersebut lebih memilih menjadikan anak-anak mereka untuk bekerja membantu perekonomian keluarga, selain itu kebanyakan orang tua didaerah pedalaman atau perbatasan enggan untuk membiarkan anaknya sekolah keluar daerah mereka karena tidak memiliki biaya untuk menyediakan tempat tinggal dan kebutuhan anaknya selama menempuh pendidikan. Dan juga, tenaga pendidik pun kebanyakan enggan untuk ditempatkan didaerah tersebut karena sarana dan prasarana yang memadai. 
Berdasarkan hal tersebut, permasalahan ini sudah sangat berjalan cukup lama dan belum terselesaikan dengan sepenuhnya, sedangkan setiap tahunnya Indonesia harus menggerakan perubahan terlebih lagi dalam bidang pendidikan agar mampu menciptakan sumber daya manusia yang berpengetahuan dan bisa unggul dalam membangun generasi yang lebih baik untuk menyongsong masa depan. Maka dari itu, harusnya pemerintah serta masyarakat harus ikut andil dalam meningkatkan pendidikan yang merata bagi keberlangsungan masa depan anak Indonesia. Bagi pemerintah harusah lebih memperhatikan pendidikan didaerah pedalaman atau perbatasan agar tidak hanya daerah perkotaan dan sekitarnya yang mampu memperoleh pendidikan dengan mudah tetapi juga daerah yang pedalaman atau perbatasan, apalagi jika ditinjau dari undang-undang yang mengatur tentang hak setiap warga negara untuk mendapatkan pendidikan. Pemerintah juga harus memikirkan cara untuk menjadikan hambatan-hambatan yang ada dalam pembangunan sekolah didaerah tersebut dapat diatasi.

Selain pemerintah, masyarakat juga harus ikut membantu peran pemerintah dalam membangun pendidikan yang merata, contohnya bagi tenaga pendidik, hendaklah juga mau ikut berpartispasi membangun pendidikan bagi anak-anak pedalaman atau perbatasan agar mereka mampu mendapatkan hak pendidikan yang sama dengan anak-anak perkotaan. Selain itu juga mensosialisaskan ke orang tua didaerah tersebut untuk juga mendukung anaknya dalam mengenyam pendidikan agar mampu menaikkan taraf hidup keluarganya ketika sudah besar nantinya. Permasalahan pendidikan di Indonesia sebenarnya bukan hanya tanggung jawab pemerintah tetapi menjadi tanggung jawab bagi seluruh warga negara Indonesia karena masa depan dari negara Indonesia juga terbentuk dari adanya sumber daya manusia yang unggul dalam bidang ilmu pengetahuan agar mampu bersaing dengan negara maju lainnya. 